EstAg 34 (1999) 249-281

\title{
El último pecado imperdonable
}

\section{Católicos divorciados vueltos a casar}

\section{CUANDO LOS PECADOS ERAN "MORTALES"}

El judaísmo ha sido llamado religión de la razón, debido a que las características de su núcleo, la Ley, le distinguieron de otras religiones. Sus prescripciones son explicadas, tienen una razón de ser. Si alguien es condenado al flagelo no deberá recibir más de 40 azotes, "no sea que al golpearle más sea excesivo el castigo, y tu hermano quede envilecido a tus ojos" (Dt 25, 1-3). Al comer la carne de los animales la sangre no puede consumirse, "pues la vida de toda carne es su sangre" y el principio vital pertenece a Dios (Lv 17, 14; Gn 9, 4). Como en otras culturas orientales, en la legislación israelita hay identificación entre lo religioso y lo social. Pero en aquéllas dicha legislación dependía más bien de la realeza, mientras el derecho israelita proviene de la alianza de Dios con su pueblo elegido. Las normas son así comprendidas, quieren ser enseñanza, en hebreo torá. Dios quiere que sus mandatos sean comprendidos y asumidos internamente1. Tal vez por eso, porque son una exigencia de Dios al hombre, también resultan ser unas leyes más humanistas, menos crueles que las de los pueblos en derredor (sólo una mutilación, Dt 25,11s; la ya mentada limitación de azotes), pues Dios ha creado al hombre a su imagen (Gn 9,6)2.

Pero igualmente, de todo ello deriva un rigorismo especial: las faltas contra Dios (idolatría, blasfemia) y contra la santidad del pueblo (bestia-

1. G. Von RAD, Teología del Antiguo Testamento. I: Las tradiciones históricas de Israel, $1969,255 \mathrm{~s}$.

2. W. EichrodT, Teología del Antiguo Testamento. I: Dios y pueblo, 1975, 71. 
lismo, sodomía) resultan imperdonables, son literalmente mortales (cf. Ex 22, 17-19; Lv 24, 14-16)3. La razón viene dada al tener en cuenta el alcance de la blasfemia. "Si un hombre peca contra otro hombre Dios será el árbitro; pero si el hombre peca contra Yavé, ¿quién intercederá por él?" $(1 \mathrm{Sm} 2,25)$. Una sociedad teocrática siempre considerará merecedoras de muerte las ofensas contra Dios 4 .

Esto parece venir de una aparentemente acertada, pero en buena lógica errada, intuición religiosa: la ofensa a Dios no puede repararse. Bien pensado, las palabras son bastante inofensivas en sí mismas. No hieren más que subjetivamente, si el blanco al que se dirigen las interpreta como insultantes, injustas o dolorosas. Ni siquiera basta que el ofensor las considere duras y humillantes. Todo depende de la valoración del que las recibe. Como suele decirse, "no ofende quien quiere, sino quien puede". $\mathrm{Y}$ resulta que nadie puede ofender verbalmente. Sólo se ofende quien se da por aludido.

La prueba está en que un mismo insulto puede ser diversamente recibido por una persona, si se lo dedica un conocido o un ignoto desharrapado. En el segundo caso se olvida en seguida ("pobre loco", se piensa). En el primero, por el contrario, escuece tenazmente. Se podría argüir que la diferencia estriba en el sujeto que lo profiere, pero esto es verdad a medias, puesto que insultadores, insultos y consecuencias son intercambiables (un chiflado puede ofender y un amigo airado no, a la misma persona, con idéntico improperio). Lo que verdaderamente cambia es la interpretación de quien recibe el insulto, la valoración del hecho o del ofensor por parte del ofendido. Si se la considera ofensa, ofende; si se la desautoriza como tal, resulta inocua. No ofende la acción o la palabra denigrantes, sino la gravedad e importancia que a ellas concede el vejados.

Esta idea puede aplicarse a Dios para señalar lo falso de la enormidad de ofenderle. Estamos de acuerdo en que su perfección nada precisa de sus criaturas. Como decimos en una oración eucarística, dirigiéndonos a Él, "Tú no necesitas nuestra alabanza, ni nuestras bendiciones te enri-

3. R. DE VAUX, Instituciones del Antiguo Testamento, 1964, 213s.

4. Así procede todavía el islamismo de hoy, como lo tenemos en el edicto del Ayatolá Jomeini contra el escritor Salman Rushdie, en 1989. Así procedió la cristiandad medieval contra los herejes. Son condenas a muerte, no por acciones abominables, sino debidas al pensamiento religioso heterodoxo u ofensivo.

5. Son ideas del cognitivismo, corriente psicológica nacida, y muy influyente, en Estados Unidos. Ver A. ElLIS, Razón y emoción en psicoterapia, 1980. 
quecen"6. Pues bien, si nada le podemos añadir, menos le podremos quitar, por más que le neguemos o blasfememos. Así lo dice el mismo santo Tomás: "Dios no recibe ofensa de nosotros, sino por obrar nosotros contra nuestro bien"7. Según esto, Dios permanecerá siempre inexpugnable a nuestra irreverencia. Tanto más, cuanto que una afrenta no es eficaz por sí misma, sino sólo desde la validación de quien es objeto de ella. En conclusión, no se puede ofender a Dios, sino sólo a los creyentes que oyen la blasfemia. De manera que todo castigo a tal presunta lesa majestad será excesivo. No existen los pecados imperdonables o irreparables por haber herido la dignidad de Dios.

A Dios se le ofende sólo en sus criaturas, en particular en el hombre, su imagen accesible a los otros seres humanos. Del mismo modo que Jesús unió -lo que tal vez es la esencia del cristianismo- amor a Dios y amor al prójimo (Mc 12,28-31), no podrá disociarse el escarnio a Dios del menoscabo del prójimo. No porque quien ofende a Dios en sí -cosa imposibleofende al prójimo, sino al revés: porque quien destruye al hombre está insultando a Dios. Así lo entendió también la primera tradición cristiana. “Si alguno dice 'amo a Dios' y aborrece a su hermano es un mentiroso; pues quien no ama a su hermano, a quien ve, no puede amar a Dios, a quien no ve" $(1 \mathrm{Jn} 4,20)$.

\section{ESA OSCURA BLASFEMIA}

"El que blasfeme contra el Espíritu Santo no tendrá perdón nunca" (Mc 3, 29). La frase suena tremenda, como si fuese posible incurrir en algo, incluso por ignorancia o descuido, para lo que no hubiera remisión

6. Misal Romano, Prefacio común IV, $2^{\mathrm{a}}$ Edición Típica 1977. Así lo expresa también Agustín, Sermones 325,1, hablando de los santos: "Ellos no necesitan de nuestras festividades, porque están gozando con los ángeles en los cielos; pero se congratulan con nosotros, no por exaltarles, sino por imitarles. Aun cuando les honremos, el homenaje nos aprovecha a nosotros, no a ellos". E. SCHILlebeECKx, Cristo, sacramento del encuentro con Dios, 1964, 9s, explicando la revelación de Dios, expone bellamente, aunque sea de modo metafísico, la inaccesibilidad de Dios. Las cosas materiales, por serlo, no pueden sustraerse a los sentidos. El ser humano, espíritu encarnado, se muestra necesariamente, dada su corporalidad, pero es inescrutable en su interioridad, a la que sólo se llega si él se abre libremente. Dios, espíritu puro, resultará radicalmente inalcanzable, a no ser que se autocomunique en su gracia.

7. Tomas DE AQUiNo, Suma contra los gentiles 3,122. 
posible. Sorprende tanto más cuanto consoladora resulta la frase anterior: "se les perdonará todo a los hijos de los hombres, los pecados y las blasfemias, por muchas que éstas sean". Al evangelio de Jesús, abrumadoramente portador de la salvación y perdón de Dios, extraña la idea de un pecado imperdonable.

El "espíritu" es el viento (pneúma, soplo; spiritus, aire). No se ve, pero se siente. Por eso se presta particularmente bien para expresar la presencia de Dios, a veces fuerte (Jc 14,6), a veces insensible y cotidiana (1Re 19, 11-13). El espíritu sería como la respiración de Dios (Jb 33, 4). Los profetas, actualizadores de la palabra de Dios en cada momento histórico, fueron precisamente ejemplos de inspiración divina: "el espíritu de Yavé irrumpió en mí" (Ez 11,5); "el espíritu del Señor está sobre mí..." (Is 61,1). Lo que el AT hebreo llamaba espíritu de Dios, será expresado en la literatura rabínica y en la LXX, y luego en el NT, como Espíritu Santo, debido a la creciente conciencia de la inaccesibilidad divina y por la reverencia que merece su nombre, que llevará también a sustituir Yavé por Señor.

Espíritu Santo es lo mismo que presencia de Dios, aliento de Yavé, fuerza divina. No es una persona distinta de Yavé, aunque se le personifica, igual que puede objetivarse el soplo emitido por un hombre y representarle. Como la respiración refleja bien las emociones humanas (atónito $=$ sin sonido, pasmado; anhelante $=$ sin aire, deseoso) el espíritu servirá para señalar su alma, la sede de los sentimientos y pensamientos, la persona misma. Los profetas, anunciadores de un advenimiento futuro de Dios, en todo su poder, hablarán adecuadamente de efusión de su Espíritu (Ez 36, 27; Jl 3,1s). Este es el ámbito desde el que debe entenderse el dicho de Jesús sobre el pecado contra el Espíritu Santo. No se trata, ni por asomo, de irreverencia hacia la tercera persona trinitaria, lo que sería un terrible anacronismo dogmático.

El pasaje sobre la imperdonable blasfemia contra el Espíritu Santo aparece en los tres sinópticos. En Lucas conformando una colección de dichos sueltos (Lc 12,10), y en Mateo y Marcos dentro de una polémica de Jesús con escribas (Mc) o fariseos (Mt) a propósito del origen de su fuerza taumatúrgica, si divina o diabólica (Mc 3, 22-30; Mt 12, 24-32). En este último encuadre se entiende bien a qué se refiere la blasfemia contra el Espíritu. Y sobre todo siguiendo a Marcos, el único que, a modo de conclusión, la explica: "Es que decían: está poseído por un espíritu inmundo"8.

8. Sobre esto ver V. TAYLOR, Evangelio según san Marcos, 1979, 272-276; R. SCHNACKENBURG, El evangelio según san Marcos. I, 1980, 96s; J. GNILKA, El evangelio según 
La blasfemia contra el Espíritu está conectada con la consideración del ministerio de Jesús. Es normal que su figura despertase discusiones (Mc 8,27s), admiración (Mc 1,28) o rechazo (Mc 3,6). Siempre ha habido y habrá interpretaciones para todos los gustos. Parafraseando el conocido adagio democrático: un hombre, una opinión. Tiene que ver con la identidad e irrepetibilidad de cada individuo. Pero lo que parece extraño, lo que va en contra de toda lógica, es que una curación pueda ser obra del maligno. Para los antiguos la enfermedad -sobre todo la que proviene del interior, sin lesión externa y de causa desconocida- es obra de malos espíritus, de lo que ofrece abundantes muestras el NT. El paralelo de Lucas del pasaje comentado comienza así: "Estaba expulsando un demonio que era mudo..." (Lc 11, 14). La misma explicación, tiene un "espíritu inmundo", se da para un epiléptico (Mc 9,25). Lo mismo se dice de quien se comporta de modo extravagante, a quien se considera loco: "vino Juan, que ni comía ni bebía, y dicen: demonio tiene" (Mt 11,18).

Pero lo que no puede ser, entonces, lo que era claro para cualquiera, es que la curación, la "expulsión de demonios", pueda provenir de Belcebú. Obrar contra el maligno significa necesariamente estar de parte de Dios. Además, si Satanás actuase contra sí mismo estaría abocado a la autodestrucción, y a nadie se le escapa la tenacidad del mal. Una expulsión de demonios sólo puede ser signo del poder de Dios, del poder de "uno más fuerte" que el mal (Lc 11, 22).

Esta es la blasfemia contra el Espíritu Santo: no reconocer, y trabucar, la presencia de Dios cuando ésta es clara, por ejemplo en la victoria sobre el dolor y la enfermedad. Se trata de mala fe, mala voluntad ${ }^{9}$. Desde luego, no se puede perdonar hacer el mal sabiendo que se obra mal, la maldad consciente. A menos que medie arrepentimiento. $Y$ arrepentirse procede de re-paenitere, penar intensamente, dolerse del mal cometido, estar dispuesto a cambiar. Pero la dureza de corazón, la ausencia de conversión, obstinarse en el mal a sabiendas, es autoexcluirse de todo perdón (incluido el divino, habría que añadir si esto no fuera pretencioso). El

san Marcos. I: Mc 1 - 8,26, 1986, 171s.177; J. MATEOS - F. CAMACHO, El evangelio de Marcos. Análisis lingüístico y comentario exegético. I, 1993, 335-343.

9. "Un pecado contra el Espíritu Santo no es simplemente un hecho, sino una disposición espiritual permanente, es una ceguera culpable por sí misma, un resistirse a la acción salvadora de Dios. En tanto que un hombre persiste obstinadamente en su oposición a Dios, se excluye a sí mismo de la salvación. Y eso es precisamente lo que acontece cuando alguien atribuye al espíritu satánico las acciones del Espíritu divino reconocibles en Jesús" (SCHNACKENBURG 97). 
anuncio de Jesús se centra en la salvación y amor de Dios, en su misericordia más allá de lo humanamente calculable. Pero debe mover a la conversión (Mt 18,23ss), al reconocimiento de la propia imperfección (Lc 13, 1-5). El dicho de Jesús sobre la blasfemia imperdonable contra el Espíritu concuerda con todo su mensaje: "convertíos y creed la buena noticia" (Mc $1,15)$.

\section{LA IMBORRABLE TRIMALDAD}

Se ha hecho famosa, poco menos que clásica, la idea de que la antigüedad cristiana tuvo tres pecados por imperdonables: adulterio, apostasía y homicidio. La Iglesia no los podía cancelar, sino sólo encomendar a la misericordia divina. Sin embargo, esto está muy lejos de la verdad. Hasta el punto que lo que en realidad hizo la Iglesia, bebiendo de la fe evangélica, fue empeñarse en dejar sentado que no había absolutamente ningún pecado irremisible. Es decir, todo lo contrario de la célebre tesis.

El esquema de la tríada tan terrible parece provenir de la confluencia y simplificación de dos nociones sobre la Iglesia antigua: su rigorismo penitencial, que de uno u otro modo es indudable; y sus enconadas polémicas sobre la remisión de algunos pecados, justamente adulterio (con Tertuliano), apostasía (con Cipriano) y homicidio (en el concilio de Ancira). De esto se dedujo que durante los tres primeros siglos la Iglesia había ido cediendo en su rigor, lo que testimoniarían los susodichos debates, hasta admitir que todos los pecados eran purgables, una vez advenida la masificación -y relajación-eclesial que supuso la paz constantiniana ${ }^{10}$.

Pero los estudios actuales llegan a la conclusión opuesta: desde el principio la Iglesia (esto es, el Magisterio y la mayoría cristiana) mantuvo la absolución de todo pecado, y las polémicas; se suscitaron precisamente por la cerrada defensa que hizo de este principio contra corrientes rigoristas. Hasta el siglo IV, en que para todos quedó clara la posibilidad abso-

10. Esta tesis fue unánime entre estudiosos católicos y protestantes de entresiglo, por lo demás de ganado prestigio: Franz Xaver Funk, Pierre Battifol, Friedrich Loofs, Adolf Harnack, Reinhold Seeberg. Sobre esto ver B. Poschmann, Paenitentia secunda. Die kirchliche Busse im ältesten Christentum bis Cyprian und Origenes. Eine dogmengeschichtliche Untersuchung, 1940, 134.481s; P. ADNÈs, La penitencia, 1981, 85-87. 
luta de reconciliación. Ésta, de todos modos, era durísima y humillante para los pecados graves ${ }^{11}$. La penitencia pública o canónica abarcaba desde la formación de un grupo especial reconocible externamente (ordo paenitentium) hasta prohibiciones permanentes para la persona absuelta (tener relaciones sexuales, ejercer cargos públicos). Además, sólo se concedía una vez, era irrepetible. No es de extrañar que en general se pospusiese para el momento de cercanía de la muerte, in extremis, y que acabara desapareciendo ante el empuje y humanidad de la penitencia tarifada12.

Hacia mitad del siglo II, Hermas clama por la conversión, cual nuevo Juan Bautista, en el yermo religioso de su tiempo. Afirma, siguiendo lo que "algunos maestros" dicen, "que no hay otra penitencia sino aquélla en que bajamos al agua"13. Pero añade a continuación, como si fuera convicción propia, y a resultas de sus visiones, que después del bautismo habrá otra y definitiva penitencia ${ }^{14}$. Esto ha dado lugar a todas las interpretaciones posibles. Desde la que le supone un renovador laxista que rompió con la dureza anterior de la Iglesia ${ }^{15}$, hasta la que le tacharía a él de rigorista, habiendo reducido a una sola penitencia posbautismal la natural y evangélica misericordia de las comunidades primeras ${ }^{16}$. En medio está la

11. Algunos Padres los resumen en la susodicha tríada, PACIANO, Exposición sobre los penitentes 4,1-5; Agustin, La fe y las obras 19,34, lo que habrá influido en su pésima fama actual. Los pecados leves se perdonaban con la limosna, el ayuno, la oración y las buenas obras.

12. Sobre esto ver C. VoGEL, Le pécheur et la pénitence dans l'église ancienne, 1966, 9-57; J. RAMOS-REGIDOR, El sacramento de la penitencia. Reflexión teológica a la luz de la Biblia, la historia y la pastoral, 1975, 177-204; ADNES (1981) 106-121. Es curioso destacar que, en la enorme evolución que se ha dado en la práctica penitencial de la Iglesia, siempre se han distinguido 3 fases principales: confesión (reconocimiento oral de culpas), penitencia (punición, acciones expiatorias por los pecados) y reconciliación (absolución, acogida en el seno de la comunidad). Cada época ha nombrado el todo desde la parte que destacaba: en la antigüedad, penitencia; en la baja Edad Media y teología tridentina, confesión; en la actualidad, reconciliación. Bien está que, resaltando este último aspecto, se haya innovado tras el Vaticano II con la posibilidad de la llamada absolución general sin confesión individual (Ritual de la Penitencia, Praenotanda 31, 1975). Pero ésta ha quedado bastante descafeinada, pues hay que "confesar individualmente a su debido tiempo los pecados graves" absueltos de modo colectivo (Ibidem, Praenotanda 33).

13. Hermas, El Pastor 31,1. Sigo la numeración moderna, cf. J.J. AYÁN CAlvo (ed.), Hermas. El Pastor, 1995, 9.

14. Ibidem 31,4-6.

15. Tesis típica decimonónica. La mantiene todavía R. Joly (ed.), Hermas. Le pasteur (Sources Chrétiennes 53bis), 1968, 22-27.

16. VOGEL 17. 
que le cree continuador de la tradición oficial, cuando la Iglesia empezó a organizar un rito comunitario de penitencia17. Ésta parece la tesis más probable: algunos pasajes mencionan como algo normal la penitencia de los cristianos ${ }^{18}$, y las frases que hablan de que "sólo hay una penitencia"19 suponen la distinción entre remisión graciosa de los pecados (bautismo) y expiación punitiva de los bautizados por sus pecados graves (penitencia) ${ }^{20}$. Por lo demás, Hermas demuestra que la Iglesia antigua tenía por remisibles todos los pecados ${ }^{21}$. Incluso aparecen algunos de la traída tríada, como apostasía y adulterio 22 .

Desde lo anterior, las expresiones del Tertuliano montanista contra la posiblidad de perdonar el adulterio no podrán ser un reproche por una novedad de la Iglesia, sino todo lo contrario, una innovación suya. La corriente montanista se distinguió precisamente como una reacción al laxismo eclesial, y al pasarse a ella, Tertuliano abjura de sus errores católicos. Escribe entonces "contra las ideas que anteriormente he compartido con ellos", y si le acusan de inconstante, responde que de sabios es la enmienda: "nadie se avergüenza de mejorar"23. A partir de ahora defenderá que hay "pecados irremisibles", que la Iglesia no puede perdonar, sino sólo dejar al juicio de Dios ${ }^{24}$. Éstos son la renombrada tríada, pero también otros, como el fraude, la blasfemia y "cualquier profanación del templo de Dios" que es el cuerpo humano25. La ascesis y tremendismo montanista.

17. ADNES (1981) 90-92.

18. Por ejemplo 13,5: Forman parte de la torre (la Iglesia) los cristianos "que han pecado y quieren arrepentirse. Por eso no son arrojados lejos de la torre, porque serán útiles para la construcción si se arrepienten"; también 1,$9 ; 6,4 ; 67-77 ; 66,4$.

19. 29,$8 ; 31,6$.

20. Sólo hay una penitencia, pero dos formas de perdón de los pecados. Tras aquélla "los días de penitencia se han acabado para todos los santos; en cambio, para los paganos hay conversión hasta el último día" $(6,5)$.

21. 6,$4 ; 10,2$.

22. 7,$4 ; 72,4 ; 29,8$.

23. La castidad 1,10.12.

$24.2,12 ; 18,18$. Esto no lo decía de católico. Entonces afirmaba con vehemencia que todos los pecados eran perdonables, La penitencia 4,$1 ; 7,9 ; 8,1$.

25 La castidad 5,12; 19,25. Otro pasaje de este escrito abundaría en la idea de la tríada: "Las Iglesias no conceden la paz ni a la idolatría ni al homicidio" $(12,11)$, además de al adulterio, tema central del libro. Pero debe ser interpretado desde su idea de que todos los pecados graves son irremisibles, y no sólo esos tres. Así que lo que Tertuliano describe es una situación de hecho: apóstatas y homicidas, al abandonar la comunidad eclesial, perdían la ocasión de hacer penitencia, ver ADNES (1981) 96, nota 14. Otro modo de entenderlo haría de esta 
La siguiente polémica sobre el poder eclesial de perdonar pecados giró en torno a la apostasía. Ésta había sido grande durante la persecución de Decio, el año 250, a diferencia de las anteriores. Al remitir, la mayoría de los lapsi (caídos) pedían volver a la Iglesia y a la eucaristía como si nada hubiera pasado, y algunos confessores (fieles en la persecución) y sacerdotes así lo concedían ${ }^{26}$, contra lo que protesta Cipriano, obispo de Cartago, que exige antes de nada la penitencia canónica ${ }^{27}$. La cuestión no es si la Iglesia puede perdonar a los apóstatas, cosa que todos parecen admitir-lapsi, confesores, sacerdotes y Cipriano-, sino cómo debe hacerlo, si ha de ser más o menos indulgente. Unicamente el presbítero de la Iglesia romana Novaciano disintió, agrupando a los descontentos en un cisma. Según ellos, la Iglesia no podía perdonar la apostasía de ninguna manera. Puede comprenderse esta postura, por lo demás minoritaria, de algunos cristianos encendidamente leales, que tras superar las penalidades de la persecución, una vez acabada ésta, se encuentran compartiendo cantos, oraciones y bendiciones con quienes no han sufrido un rasguño, gracias a su oportuna idolatría.

En cuanto al último de los pecados supuestamente imperdonables, el homicidio, aparte del Tertuliano montanista, no hay más base para atribuirle esa cualidad que la mención del concilio de Ancira (actual Ankara, Turquía), el año 314, al determinar la penitencia oficial que corresponde a dicho pecado, según hubiera sido voluntario o no28. Pero de aquí no se puede colegir que hasta entonces no se perdonase. Más bien, teniendo en cuenta lo anteriormente dicho, justamente lo contrario. Ahora sólo se regula.

Por tanto, la Iglesia nunca ha considerado ningún pecado como inamisible. Esto es consecuencia de su doctrina sobre el poder salvífico de

frase un deseo de Tertuliano: las Iglesias no "deben" perdonar tales pecados. Sus siguientes palabras van en este sentido: "no se puede creer que los apóstoles hayan abandonado este principio suyo". Esto probaría que la Iglesia perdonaba todos los pecados desde el principio, y Tertuliano critica a los obispos, teóricos mantenedores de la tradición apostólica, haberles traicidonado. Ve afirmado claramente dicho principio apostólico en Hch 15,20: abstenerse de sacrificios idolátricos, de la fornicación y de la sangre, es para él símbolo de los pecados irremisibles (La castidad 12,4-6).

26. Cipriano, Cartas 22,2,1;23.

27. Cipriano, Cartas $15,1,2 ; 17,2,1 ; 16,2,3$.

28. Cánones 21 y 22: Los asesinos voluntarios estarían sometidos a la penitencia canónica de por vida, y podrían recibir la comunión al final de sus días. El homicidio sin premeditación requería 7 años de penitencia. 
Dios, y la capacidad universal de la redención de Jesucristo. Los problemas internos que tuvo en su primera historia se debieron a la apología que hizo de esta convicción.

\section{EL DIVORCIO Y LA IGLESIA, PAREJA DE HECHO}

El matrimonio es una institución universal. El proceso de organización de las diversas culturas humanas incluía siempre cierta normatividad en las relaciones de pareja y de familia. Sin duda porque, como ya dijera Aristóteles y se repite hoy, la familia es la célula de la sociedad 29 . Idéntica universalidad institucional corresponde al divorcio. Es decir, la reglamentación matrimonial comportaba también los aspectos de su ruptura ${ }^{30}$. De manera que el divorcio es tan antiguo y general como el matrimonio. Como las paralelas del axioma de Euclides, como las dos caras de toda moneda, matrimonio y divorcio son inseparables e intocables entre sí. El antiguo Israel participaba de esta idea legitimadora del divorcio (Dt 24, $1-4)$.

\section{Jesús y la norma de la indisolubilidad}

En esta situación tenían que sorprender sobremanera las palabras de Jesús condenando el divorcio, tanto a sus coetáneos como a la Iglesia cristiana posterior. Seguramente todos asumirían el comentario que luego hacen los discípulos: entonces más vale no casarse (Mt 19,10).

Los tres sinópticos reportan de modo sustancialmente idéntico, reflejando la novedad que supuso, la palabra de Jesús sobre la indisolubilidad del compromiso matrimonial -Mateo por partida doble-. Quien se divorcie de su mujer, dicen, comete adulterio (Mt 5, 32; 19, 9; Mc 10, 11s; Lc 16,18). Ante tal nitidez, las divergencias de expresión se desvanecen ${ }^{31}$.

29. ARISTOTELES, Ética nicomáquea 1162a,15-20.

30. Ya desde el código de Hammurabi, la legislación más antigua conocida. Ver A. VILLIEN, Divorce: Dictionnaire de théologie catholique IV/2, 1924, 1456-1458.

31. Sobre las diferentes formulaciones sinópticas del mismo dicho de Jesús, ver $\mathrm{H}$. BaltensweIler, Die Ehe im Neuen Testament. Exegetische Untersuchungen über Ehe, Ehelosigkeit und Ehescheidung, 1967, 59-71. El lógion más antiguo sería el referido por Lucas, 
En cuanto al contexto, que nos permita captar mejor el sentido de sus palabras. En Lucas es un dicho suelto, si bien resonando el tema del valor de la Ley (vv. 16-17). Mt 5, 31 lo inserta entre las antítesis de Jesús, en las que interioriza (radicalizándola) o corrige la Ley mosaica; en este caso la corrige, a propósito de la antítesis anterior sobre el adulterio (vv. 27-28). Finalmente, Marcos y Mt 19, 9 enmarcan la sentencia dentro de una discusión de Jesús con los fariseos ${ }^{32}$.

Comparando entre sí las perícopas de Mc 10 y Mt 19, Mateo dependería de $\operatorname{Marcos}^{33}$, y la pregunta inicial es lo que más les separa, mientras lo demás es un cambio de orden en la marcha de la discusión que no altera el producto. En Marcos se le inquiere sobre el divorcio en general, si "puede el marido repudiar a la mujer". En Mateo, en cambio, la pregunta es si "¿puede uno repudiar a su mujer por un motivo cualquiera?"; es decir, se presenta una cuestión candente en el judaísmo de entonces, a saber, cuáles son las razones que justifican el divorcio. Ambos, Marcos y Mateo, han acomodado la cuestión a la situación de sus comunidades. El ambiente romano de la comunidad de Marcos admite el divorcio sin más, y esa mentalidad se quiere a confrontar. Entretanto, la comunidad judeocristiana de Mateo ha heredado una polémica intrajudaica, que es la que trasluce la pregunta. Los rabinos disputaban sobre el significado de la

que sonaría: "el que repudie a su mujer comete adulterio, y el que se case con una repudiada comete adulterio". Las razones son que sigue el derecho hebreo, en el que sólo el hombre puede divorciarse y escribir un documento de repudio para permitir un nuevo matrimonio a la mujer. La novedad de Jesús es que a los dos casos llama adulterio. Lc 16,18 y Mt 5,31 son parecidos, dependen de Q, por lo que "y se casa con otra", que no está en Mt, sería añadido lucano. La característica mateana "la hace ser adúltera" se formaría como complementaria de Mt 19,9. Mc 10,11s es la acomodación del dicho al ambiente romano, que reconocía también el derecho de divorcio a la esposa, impensable para los judíos. En cuanto a Mt 19,9, contiene la formulación más simplificada, y dependería, dado el idéntico contexto de discusión, de la fuente Mc.

32. En el caso de la polémica antifarisaica relatada por Marcos y Mateo, el contexto no puede servirnos para interpretar el dicho jesuano. El proceso de formación de la perícopa habría sido el contrario, el lógion tan novedoso de Jesús fue conservado creando una historia que lo hiciera didácticamente transmisible en la catequésis cristiana y fácilmente recordable para los oyentes. Es un principio típico de la Formgeschichte, para la que cada forma evangélica nos remite a la situación de la comunidad primitiva, más que a la persona de Jesús. Esto se demuestra aquí porque el logion tiene otro contexto en Q (Mt 5,31; Lc 16,18); también porque se cita la Escritura según los LXX, lo que indica que el revestimiento de discusión ha nacido de comentarios y catequesis comunitarios. Ver J. GNILKA, El evangelio según san Marcos. II: $M c$ 8,27 - 16,20, 1986, 79-87.

33. Siguiendo la teoría de las dos fuentes sinópticas, apoyada además en correcciones lingüísticas típicas de Mateo sobre el texto de Marcos, BALTENSWEILER 83s. 
condición mosaica para el repudio: encontrar en la esposa "algo vergonzoso" (Dt 24,1). El rabino Shammai la entendía de modo literal, refiriéndola al comportamiento deshonesto, mientras el rabino Hillel lo hacía en sentido amplio. incluyendo en eso hacer mal la comida (todavía hasta hace poco una de las obligaciones centrales de la esposa) ${ }^{34}$. Se pide una solución a tal dilema esacolástico.

De cualquier manera, sea cual fuere el contexto original, todos coinciden en señalar que se trató de una contraposición de Jesús a la legislacion judía. y en ello captamos perfectamente cuál fue la intención de su sentencia rechazando todo divorcio. Jesús no pretende crear una nueva ley. Se mire su afirmación por donde se mire siempre resalta el matiz antijurídico. Está claro en las antítesis mateanas y se percibe también en el marco temático lucano del dicho. En la discusión con los fariseos, mientras éstos argumentan desde la Ley, Jesús la sobrevuela, remontándose a la creación, a la idea originaria de Dios. Es su modo típico de actuar, es conocida la postura crítica de Jesús respecto de la Ley (cf. Mc 2, 27; 7, 1ss). Parece pensar que quien se aferra estrictamente a lo mandado, en su relación con Dios, se comporta como un ventajista: se compromete hasta donde marca la norma, nunca más allá. Es como el que se considera buen cristiano, o hijo obediente de la Iglesia, porque va a misa los domingos, sin necesitar nada más. La comodidad aplicada a la moral religiosa. Jesús pide lo contrario, la entrega total y sin condiciones a Dios, en todo momento y lugar, sin escapismos legales. "Sed perfectos como vuestro Padre celestial es perfecto" (Mt 5, 48). No se puede limitar con normas la obediencia a Dios.

Pero entonces, el dicho de Jesús contra el divorcio, la petición de indisolubilidad, no puede interpretarse como una ley: jes lo que acaba de criticar! Los mandatos de Jesús son exigencias religiosas que apelan a la conciencia, que encaminan a la dicha interior cuando se siguen y deben mover a la conversión cuando se infringen. No son códigos jurídicos de obligado cumplimiento externo, que impliquen exclusión comunitaria en caso de conculcarse. La diferencia se percibe al comparar en las antítesis (Mt 5, 21-48) el mandato de la indisolubilidad con los otros mandatos. Todas las antítesis (no ofender al hermano, no adulterar de corazón, no jurar en modo alguno, no resistir al mal, amar a los enemigos) han sido

34. H.L. Strack - P. Billerbeck, Kommentar zum Neuen Testament aus Talmud und Midrasch. I: Das Evangelium nach Matthäus, 1956, 312-321. 
captadas universalmente como ideales éticos de conciencia, y no como imposiciones externas para fijar quién pertenece a la Iglesia y quién no -la Iglesia, sabemos, lo es también de pecadores-. Todas excepto la referida a no divorciarse. La Iglesia actual equivoca en este punto el nivel hermenéutico, al tomar la indisolubilidad como precepto legal externo, en vez de entenderla como ideal de perfección religiosa.

Sin embargo, como ideal religioso ha entendido toda la tradición cristiana la norma de la indisolubilidad matrimonial. Y además de modo constante. No es algo excepcional como pudiera pensarse a primera vista. Llega incluso hasta el día de hoy, aunque se solapa inconscientemente. El caso es que la Iglesia siempre ha buscado reglamentar en su seno la ruptura conyugal.

\section{La Iglesia apostólica}

Pablo, en su solicitud pastoral por las Iglesias que ha fundado, contesta a los problemas que éstas le presentan. Nacen así sus cartas. Una de las cuestiones que le plantean tiene que ver, cómo no, con el divorcio. Queda constancia de ello en el capítulo séptimo de su primera Carta a los Corintios. "A los casados les ordeno, no yo sino el Señor, que la mujer no se separe del marido" (v. 10). La novedosa exigencia de Jesús ha quedado bien grabada. No se puede enmendar. Por si no estaba claro, Pablo la repite para el esposo: "y que el marido no despida a su mujer" (v.11). Los diferentes términos empleados según el cónyuge -la mujer se separa, el marido despide - reflejan su formación judía ${ }^{35}$, pero la aplicación de la norma es la misma para ambos. Con todo, ya considera el fracaso matrimonial (v. 11). En tal caso admite la separación, aunque no un nuevo matrimonio, para dejar abierta la posibilidad de reconciliación ${ }^{36}$. La separación sin

35. En la legislación hebraica únicamente el esposo puede repudiar legalmente a la mujer (Dt 24,1-4). A ésta sólo le queda marcharse de casa, o solicitar el permiso de divorcio por cuestiones especiales concernientes al marido: enfermedad, profesión pestilente, negligencia económica, etc. Ver STRACK-BILLERBECK I, 318s.

36. Pablo dice esto hablando sólo de la esposa: "en el caso de separarse, que no vuelva a casarse, o que se reconcilie con su marido". ¿Significa esto que se permite al marido otro matrimonio tras la separación? En otros lugares de este capítulo Pablo aplica lo mismo a los dos consortes (vy. 2-4.12-14.16.33s). Esto sólo puede significar que también en este caso Pablo supone idéntica obligación para el marido. Ver P.ADNES, El matrimonio, 1969, 54; S. VIDAL, Las cartas originales de Pablo, 1996,182: de otro modo no sería posible al marido la reconciliación con su mujer. 
nuevo matrimonio será práctica eclesial hasta el día de hoy. Ahora bien, esto ya supone la quiebra del precepto de la indisolubilidad.

Pablo innova más en su siguiente excepción de la indisolubilidad. Considera el caso de los matrimonios mixtos (1Cor 7, 12-16), que no son exactamente igual que los nuestros ${ }^{37}$, sino matrimonios paganos, uno de cuyos cónyuges se ha convertido al cristianismo. A los que son cristianos Pablo les pide que se casen "en el Señor" (v. 39), esto es, con otro cristiano. El advenimiento de la fe cristiana daba lugar a estas situaciones, en las que un esposo se bautizaba y el otro no. En este caso, si la parte pagana desea mantener el matrimonio, éste debe mantenerse. La comparte y los hijos paganos quedan "santificados" por su relación con el cristiano. Para Pablo, los cristianos son santos (1Cor 1,$2 ; 2$ Cor 1,1$)$ en el sentido de elegidos de Dios, acercados a Él, distinguidos de lo profano ${ }^{38}$. La unión íntima con un cristiano, propiciada por pertenecer a su núcleo familiar, introduce a estas personas en el ámbito de la santidad, y tal vez puedan llegar a bautizarse (v. 16).

Pero "si la parte no creyente quiere separarse, que se separe, en este caso el hermano o la hermana no están ligados" (v. 15a). Pablo no menciona la posibilidad de volver a casarse para el cristiano, y antes ha hablado de separación (o despido) sin nuevo matrimonio (v. 11). Sin embargo ahora parece ser distinto. No dice a tales parejas lo que antes explicitaba, "no vuelvan a casarse", sino que emplea la fuerte expresión "no están ligados" 39 Además, ahora tiene clara conciencia de estar creando respecto de las palabras de Jesús: "digo yo, no el Señor" (v. 12). De todos modos, Pablo recomienda el fin del matrimonio. Se ha topado con un problema

37. Matrimonio mixto es el formado por católico y acatólico, para lo que el católico necesita licencia eclesial (CIC 1124). Matrimonio dispar es el compuesto por bautizado y no bautizado, inválido sin dispensa (CIC 1086). Pablo habla de matrimonios devenidos mixtos, no mixtos o dispares en el momento de la celebración.

38. Es una idea antigua, típica también del AT. Santidad como esfera divina, y por tanto diversidad, contrapuesta a mundanidad. Dios es el tres veces santo (Is 6,3), el totalmente Otro de la teología dialéctica. Israel, por ser su pueblo, debe distinguirse ritualmente, manifestar su consagración (Lv 19,2ss). Ver R. OTTO, Lo santo. Lo racional y lo irracional en la idea de Dios, 1965.

39. Literalmente "no están esclavizados" (ou dedoúlotai), no están sujetos al vínculo. En este mismo sentido de permisión de otro matrimonio lo interpretan BALTENSWEILER 191-196; ADNES (1969) 55s; VIDAL 182s. Además, anteriormente Pablo no admitía nuevo matrimonio entre cristianos tras la separación para favorecer la reconciliación. Si ahora no dice nada será porque piensa que el pagano no puede comprender tal esfuerzo. En consecuencia deja libre del vínculo al cristiano. 
nuevo, el de la división que la fe cristiana, con sus radicales exigencias, provoca en un matrimonio cuando sólo un cónyuge se convierte. La distinta mentalidad, el cambio de vida que implicaba, hacían imposible la conviviencia. Por eso es preferible la ruptura, pues "para vivir en paz os llamó el Señor" (v. 15b). Pablo entiende la indisolubilidad matrimonial como algo a cumplir, naturalmente. Pero también se da cuenta de que a veces no es posible, que las circunstancias pueden ser excesivamente adversas. $Y$ entonces prefiere transigir y alentar a reiniciar la vida cristiana, pues el Señor también llama a la felicidad terrena.

Con Mateo sucede, salvando las distancias, algo parecido. Su transacción con la realidad se esconde en su particular, pequeña y enigmática apostilla al dicho jesuano, presente en las dos versiones que nos trasmite: indisolubilidad, sí, "excepto en caso de impureza" (Mt 5, 32; 19, 9). Semejante coletilla ha provocado pertinaces cefaleas, que perviven hasta hoy mismo desde el ayer cristiano. No es para menos. La limpia novedad de la enseñanza de Jesús empañada con unas simples palabras. ¿Qué querrán decir? Las explicaciones distan mucho de ser unánimes, aunque actualmente pueden concentrarse en dos. Todo depende del sentido que se dé a la palabra impureza.

Una interpretación, común entre los cristianos desde el principio, entiende la palabra, dado que se está hablando de matrimonio, como adulterio $^{40}$. Sería, entonces, una excepción a la norma general de la indisolubilidad. Así lo entendieron todos los Padres de la Iglesia. Su problema fue cómo armonizar la excepción mateana con la norma absoluta de los otros sinópticos. La solución quedó apuntada en Hermas, que sigue la idea de Pablo, separación sin nuevo matrimonio para posibilitar una reconciliación ${ }^{41}$. Tiempo después se formará una casuística que considera que la excepción por adulterio permite otro matrimonio a la parte ino-

40. La objeción principal es que para adulterio el griego tiene una palabra propia, moicheía, que no es lo mismo que porneía (impureza, deshonestidad). Las dos palabras griegas quedan también diferenciadas en el NT (Mt 15,19; 1Cor 6,9). Porneía trataría entonces de aclarar el "algo vergonzoso" judaico que justificaba el divorcio (Dt 24,1). Así es como comienza la perícopa de Mt 19,9, que pide a Jesús que solucione el contencioso Hillel-Shammai, cuya respuesta es el caso de porneía-deshonestidad, esto es, lo que propugnaba Shammai. No habría que entender la palabra como adulterio. El sentido de deshonestidad sería el de desvergüenza sexual, tanto íntima conyugal como social. Para todo esto ver BALTENSWEILER 87-102; ADNES (1969) 43-48; G. CERETI, Matrimonio e indissolubilità: nuove prospettive, 1971, 145-154.

41. Hermas, El Pastor 29,6-8. Jeronimo, Comentario al evangelio de Mateo 19,9, fijará 
cente. En cualquier caso, todos reconocen que la indisolubilidad no ha sido posible, que el adulterio disuelve el matrimonio.

La segunda interpretación explica la palabra en cuestión desde otros pasajes del Nuevo Testamento, lo que cambia las cosas totalmente, como de la noche al día. En una de sus cartas, Pablo se echa las manos a la cabeza ante la cohabitación de un hombre con su madrastra, unión que llama impureza (1Cor 5, 1). Tales matrimonios no eran escandalosos para los corintios, pero sí para la mentalidad judía, pues contravienen la Ley: "No descubrirás la desnudez de la mujer de tu padre; es la misma desnudez de tu padre" ( $\operatorname{Lv} 18,8)$. El concilio de Jerusalén ya había tratado el tema. Tuvo que lidiar con la convivencia entre cristianos venidos del judaísmo y procedentes de la gentilidad, cuyas diferentes ideas y costumbres volvían chirriante. Los acuerdos a que llegaron proponían a los gentil-cristianos unas prohibiciones mínimas de limpieza religiosa: comer carne sacrificada a los dioses, comer sangre o animales sin desangrar, e impureza (Hch 15, 20.29). Son normas sobre cosas que ofenden a los judíos, aunque no a los gentiles, y que éstos deben evitar para una armoniosa relación intercristiana ${ }^{42}$. Impureza, entonces, no significaría adulterio, problemático para todos, sino, como en el caso de Pablo, matrimonio incestuoso a los ojos de la cultura judía. Aplicando este significado al inciso mateano, éste no sería una excepción a la indisolubilidad, sino que querría apartar de ella a los matrimonios que no lo eran auténticamente, que obviamente debían separarse 43 .

esta interpretación, que será la postura tradicional católica, aunque sin pensar ya en una hipotética reconciliación. Esta explicación ha sido recuperada desde la exégesis moderna (poniendo deshonestidad en vez de adulterio) por J. DuPONT, Mariage et divorce selon l'Évangile: Matthieu 19,3-12 et parallèles, 1959. Una variante curiosa es la de AGUSTIN, Las uniones adulterinas 1,11: la excepción de Mateo expresaría sólo que el evangelista no quiere tratar del adulterio.

42. Comer idolotitos y sangre era desconocer la unicidad de Dios y que la vida -simbolizada por la sangre- sólo le pertenece a Él, dogmas fundamentales del judaísmo (Dt 5,7; Gn 9,4). De hecho, se justifican tales vetos del concilio porque provienen de Moisés (Hch 20,21). Porneía, en el mismo sentido, recordaría las prohibiciones de incesto de la tradición hebrea, tachadas de impureza ( Lv 18,1-30).

43. Esta interpretación de porneía es reciente. Comenzó a mitad del siglo XIX entre estudiosos católicos, preocupados por la no contradicción de los evangelios, y ha sido precisada en el nuestro por J. BONSIRVEN, Le divorce dans le Nouveau Testament, 1948, apoyado por muchos (también BALTENSWEILER 101s). La objeción arguiida es que Mateo habla de repudio masculino justificado por porneía, que aludiría a una actitud de la esposa, y no a la situación del matrimonio (así DuPONT 113s). 
Pero sea cual fuere la interpretación correcta, la cláusula de Mateo no procedería de Jesús. Los otros testimonios neotestamentarios sobre la indisolubilidad (1Cor 7, 10s; Mc 10,11s; Lc 16,18) no la incluyen. Así que Mateo pierde por 3-1. Estamos, entonces, ante una adaptación del dicho de Jesús a los problemas concretos de la comunidad mateana. Lo que significa que no entiende el susodicho dicho como una ley inmutable y voraz en toda ocasión, sinọ como una norma ideal que, manteniéndose firme, asume también la flaqueza humana al aplicarse. Si impureza indica la deshonestidad de la esposa, Mateo ha amoldado el dicho a la mentalidad judeo-cristiana a que se dirige, tan acuñada en el judaísmo que no puede entender que la inmoralidad de la mujer deje incólume un matrimonio. Mateo restringe al máximo, entonces, en coincidencia con una escuela rabínica de la época, los motivos de repudio ${ }^{44}$. $\mathrm{Si}$, por el contrario, impureza se refiere al matrimonio ilícito del judaísmo, también está adecuando la exigencia de Jesús a una determinada situación comunitaria. En la Iglesia de Mateo convivían dificultosamente judíos y gentiles, entre otras cosas por captar de modo diferente hasta dónde alcanzaba el incesto y la impureza derivada. Mateo, desde el lado judío, recordaría a los gentiles que nadie puede valerse de la palabra del Señor para sostener un casamiento entre parientes.

\section{Doctrina patrística}

La postura de los Padres respecto a la indisolubilidad va a ser muy importante, porque en ella se asienta la actual teología y praxis eclesiales.

Ultimamente se ha discutido mucho sobre la posibilidad de que algunos Padres hubieran permitido el divorcio y nuevo matrimonio en ciertos casos, por ejemplo, adulterio de la mujer. De hecho, los incisos de Mateo los entienden siempre como adulterio, y por tanto, en cuanto excepción a la norma general. El lenguaje patrístico deviene en este caso muy duro, afirmando claramente la "disolución" o "ruptura" del matrimonio 45 .

44. ¿Permitiría Mateo en este caso un nuevo matrimonio? Imposible saberlo. El precedente paulino $(1 \mathrm{Cor} 7,11)$ podría hacer pensar que no. Pero su acomodación a la comunidad judaica diría lo contrario.

45. Parece haber roto el fuego sobre la posible permisividad patrística un libro de V.J. 
En realidad, hay una gran coincidencia entre los Padres sobre este tema. A la hora de interpretar los textos del Nuevo Testamento, parten del axioma de que la Escritura no puede contradecirse, y si se diera este caso, no sería más que apariencia, debido a la humana cortedad de entendederas ${ }^{46}$. Será necesario, piensan, afinar la mirada, para captar su profunda complementariedad concordante. Sobre la indisolubilidad, su conclusión va a ser justamente esa, surgida de hilar internamente las rupturas superficiales. Juntan así Mc 10,11s/Lc 16, 18 con 1Cor 7,11, pegándole también Mt 5,32/19, 9. El resultado es el siguiente: el matrimonio es absolutamente indisoluble (como se dice en los sinópticos); pero en caso de adulterio (previsto en Mateo) podrá darse separación, aunque sin nuevo matrimonio (que es lo expresado por Pablo). Esto se dice ya con Hermas, primer testimonio patrístico sobre el problema del adulterio en la vida cristiana ${ }^{47}$, y recorre permanentemente, de oriente a occidente y durante los cinco primeros siglos, los escritos de los Padres ${ }^{48}$.

Pospishil, Divorce and Remarriage. Towards a New Catholic Teaching, 1967, escrito al calor de la renovación conciliar. Le han seguido J. MoINGT, Le divorce pour motif d'impudicité (Matthieu 5,32; 19,9): Recherches de Science Religieuse 56, 1968, 337-384; P. NAuTIN, Divorce et remariage dans la tradition de l'Église latine: Recherches de Science Religieuse 62, 1974, 754. A ellos se ha opuesto H. CROUZEL, L'Eglise primitive face au divorce. Du premier au cinquième siècle, 1971; IDEM, La indisolubilidad del matrimonio en los Padres de la Iglesia: T. GARCIA BARBERENA (ed.), El vínculo matrimonial. ¿Divorcio o indisolubilidad?, 1978, 61-116. Hay que dar la razón a CROUZEL. En primer lugar por el estudio tan detallado que hace, a diferencia del de los otros, más general o limitado. En segundo lugar, porque entiende cada pasaje ambiguo dentro del contexto de la obra, en vez de aisladamente. Finalmente, los otros autores se apoyan excesivamente en el argumento del silencio (si no se condena explícitamente el divorcio significa que se admite) o en la simple deducción (las palabras "ruptura" o "disolución" matrimonial se entienden desde la cultura profana, que era divorcista). Sin embargo, para resolver tales implícitos es mejor acudir, como hace CROUZEL, a las afirmaciones generales de los Padres, siempre antidivorcistas y con frecuencia críticas con la legislación romana.

46. Agustin, Las uniones adulterinas 1,11: "No se puede pensar que los evangelistas, cuando hablan de la misma cosa pero con distintas palabras, puedan no concordar en idéntico significado".

47. Hermas, El Pastor 29,4-6: "Si uno tiene una mujer que cree en el Señor y la encuentra en adulterio, ¿peca el hombre si convive con ella? (...) Si el hombre conoce el pecado de su mujer, y ésta no se arrepiente sino que persiste en su adulterio, y el hombre convive con ella, entonces es reo del pecado de aquélla y cómplice del adulterio. (...) Que la repudie y el hombre viva solo. Pero, si después de haber repudiado a su mujer, se casa con otra, también éste comete adulterio".

48. CROUZEL (1971) 359ss; (1978) 115s, resalta la unanimidad total que se da, exceptuando el llamado Ambrosiáster, esto es, pseudo Ambrosio: “un desconocido", dice. 
En el caso de adulterio, los Padres han llegado así a una solución propia, fresca. Dicen que en ese caso es necesario el divorcio, que el matrimonio ha quedado destruido. Pero en ningún caso permiten otra boda viviendo el primer cónyuge. La disolución de que hablan, por tanto, se refiere sólo a la vida común, que debe ser concluida. Desaparecida ésta, si no aceptan un nuevo matrimonio es porque piensan que continúa existiendo un vínculo entre los consortes, más allá de la ausencia de cohabitación. Pablo y Hermas lo impedían por razones prácticas, para favorecer la reconciliación, y más tarde, cuando ésta no se prevé, va a justificarse teológicamente. Será consecuencia de la idea del matrimonio como misterio-sacramento, apuntado en la Escritura (Ef 5,32). Es decir, en el compromiso conyugal cristiano se manifiesta, se toca, una realidad religiosa, el amor de Cristo a su iglesia, que es definitiva, imperecedera. Tal significación no puede destruirse, salvo con la muerte de un cónyuge, e impide entretanto nuevas nupcias ${ }^{49}$. Por eso se exige a la comparte inocente de adulterio la separación del adúltero, para no manchar la santidad del matrimonio. Ha nacido así lo que posteriormente se llamará separatio manente vinculo ${ }^{50}$, separación de hecho pero no de derecho, el divorcio incompleto o separación de cuerpos.

La patrística resolvió así el precepto de la indisolubilidad, entendiéndolo como referido al sacramento, o sentido profundo, del matrimonio, pero no a su sentido inmediato, o convivencia. Admiten la disolución de la vida común por el pecado humano, pero en ningún caso la del vínculo sagrado. Esta idea va a marcar la doctrina cristiana del matrimonio. En realidad parece mitificarlo, porque ya no va a consistir en el hecho y voluntad de una vida compartida, sino que puede darse también sin el compromiso de los consortes. En efecto, como todos los sacramentos, el del matrimonio es una realidad existencial que señala otra teológica, influyendo después la segunda en la primera. Sin embargo, se ha procedido sólo al revés: lo trascendente significado determina completamente lo humano. Esto supone mitificar el matrimonio: no consiste tanto en la vida común cuanto en lo que indica, y aunque la vida común desaparezca sigue habiendo matrimonio. El matrimonio puede ser, simplemente, el recuerdo de una decisión fallida, o la prohibición de casarse de nuevo. Pero esto

49. Agustin, La bondad del matrimonio 24,32, explica la sacramentalidad, o significación sagrada del matrimonio, como indisolubilidad. Lo mismo en Comentario literal al Génesis $9,7,12$.

50. Título de un apartado del Codex Iuris Canonici (CIC) 1151-1155). 
tiene poco que ver con una idea personalista del matrimonio, e incluso con el sentido común.

En compensación, la patrística manifiesta cierta tolerancia hacia el incumplimiento del mandato de no reesposarse en vida del primer cónyuge. Es famoso el comentario de Orígenes: "Contrariamente a la Escritura, algunos jefes de la Iglesia han permitido un nuevo matrimonio a una mujer cuyo marido vivía. Lo han hecho a pesar de que está escrito: 'la mujer está ligada a su marido mientras él viva', y 'mientras vive el marido será llamada adúltera la mujer que se une a otro hombre'. Sin embargo, no han actuado así sin razón. Verdaderamente han permitido esta unión para evitar males mayores, a pesar de la ley primitiva trasmitida por las Escrituras"s1. Queda claro que lo que han hecho tales obispos no es la norma, Orígenes machaca que se ha ido contra la Escritura. Pero reconoce que no es algo "sin razón", por excepcional que sea. Hay otros testimonios semejantes 52 . A pesar de considerarlo ya una clara ley intraeclesial, no desdeñan poner en tierra el principio de la indisolubilidad, acomodándolo a situaciones dolorosas individuales.

\section{Las tradiciones eclesiales}

Las diferentes etapas de la Iglesia cristiana muestran sus vaivenes a la hora de integrar la exigencia de la indisolubilidad en la dura experiencia cotidiana. Si en los cinco primeros siglos la teología patrística abogó acorde por la irrompibilidad absoluta del matrimonio -sólo alterada aceptablemente por la separación continente-, la praxis eclesial distó

51. Comentario sobre Mateo 14,23.

52. BASIllo DE CESAREA, Cartas 188,9, juzga la conducta del marido que abandonado por su mujer ha buscado otra, como "excusable", y que la que vive con él "no merece condena". Más que reconocer la nueva unión, manifiesta cierta indulgencia ante tortuosas realidades de pareja. En otro pasaje, Cartas 199,26, parece repetir la idea de Orígenes: hay que tolerar las uniones irregulares, sin dejar de someterlas a la penitencia, "por temor a que se produzca algo peor". Para AGUSTIN, Las uniones adulterinas 1,9, quien vuelve a casarse, tras el adulterio de su esposa, es "menos culpable" que quien lo hace sin causa. Y en La fe y las obras 19,35, dirá del mismo que "peca en modo digno de perdón". El papa LEON I, Carta a Nicetas de Aquilea 159 , acepta que la esposa recasada porque su marido ha desaparecido como prisionero de guerra, pueda mantener su segunda unión tras el retorno del primer marido, aunque reconoce que el matrimonio válido es el primero. Si bien son pocos testimonios, no se puede negar que son altamente cualificados. En otro orden de cosas AMBrosiASTER, Comentario sobre la I carta a los Corintios 7,10-11.15, es el único escritor de la patrística que admite el divorcio y nuevo casamiento del marido por adulterio de la esposa, aunque no viceversa, basándose en los inci- 
mucho de realizarla. La legislación del imperio romano, que tenía en el consentimiento mutuo o unilateral la forma más común de divorcio, era terriblemente contraria a la mentalidad evangélica. Los emperadores cristianos apenas si intentaron rebajar esta permisividad divorcista. A lo más que llegaron fue a penalizar, declarando ilícitos y sin derecho a recobrar dote y donación, algunos motivos de divorcio, pero de ningún modo a afirmarlos inválidos 53 . Cuando las costumbres germánicas se mezclen con las romanas surgirán nuevos supuestos de divorcio, dependientes ahora de la nueva cultura feudal. La fe cristiana se ve vapuleada por este contexto y sólo parece poder contribuir a la confusión.

Mientras los concilios de Elvira y de Arlés trasparentan cierta indulgencia hacia el hecho divorcio, los de Cartago y Angers, en regiones y fechas cercanas, mantienen inflexibles lo contrario ${ }^{54}$. Los siguientes siglos renuevan parecidas contraposiciones conciliares. Algo semejante ocurre con las decretales (cartas normativas) de los papas, en las que unos se inclinan a tolerar situaciones de divorcio mientras otros no admiten nin-

sos mateanos. Es igualmente el único que permite al consorte cristiano casarse de nuevo si es abandonado por el pagano, interpretando así 1Cor 7,15. CROUzEL (1971) 273.380, insiste en que éste actúa como exégeta, más que trasmitir una práctica de la Iglesia.

53. Sobre todo lo que sigue ver T. GARCIA BARBERENA (ed.), El vínculo matrimonial. ¿Divorcio o indisolubilidad, 1978; J. GAUDEMET, El matrimonio en Occidente, 1993. Es curiosa la constatación de A. GARCIA Y GARCIA: "Las legislaciones modernas, por muy secularizadas que parezcan, parten generalmente del concepto cristiano del matrimonio (indisoluble), permitiendo su disolución en casos delimitados. Si partieran del concepto romano, su actitud sería inversa: divorcio siempre válido, aunque en algunos casos se considerase ilícito" (La indisolubilidad matrimonial en el primer milenio, con especial referencia a los textos divorcistas: GARCIA BARBERENA 122).

54. En Elvira (cerca de Granada), hacia el 305, la esposa que deja a su marido "sin causa antecendente" para casarse con otro queda excomulgada (canon 8); pero si lo hace de un "marido adúlterio y cristiano" se la podría admitir a la comunión en caso de grave enfermedad (canon 9). Se mitiga el castigo en los casos que recuerdan las excepciones de Mateo y de Pablo: desde Mateo se beneficia la mujer por adulterio del marido, y desde Pablo se admite que la creyente tome la iniciativa dejando al no cristiano. ¿Permite el concilio lo mismo al marido en los mismos supuestos? Tal vez se tenía por evidente, aunque nada se dice. El patriarcalismo cultural lo hace más que probable. De esto habla justamente el concilio de Arlés (sureste de Francia), el 314, al poco tiempo, reuniendo a obispos representantes de todo el Occidente romano. Prohíbe el matrimonio a los maridos de esposas adúlteras, pero no lo hace con mucha convicción: "se les aconsejará en la medida de lo posible que no tomen otra mujer" (canon 10), y sin ninguna sanción de suceder lo contrario. Por contra, el canon 8 del XI concilio de Cartago (actual Túnez), el 407, y el canon 6 de Angers (oeste de Francia, año 453), reafirman el principio absoluto de la indisolubilidad. 
guna ${ }^{55}$. Las decisiones conciliares y papales, ya contradictorias, serán recogidas en colecciones canónicas y penitenciales, hechas por autores anónimos sin refrendo oficial, que añaden en dichos escritos decisiones de la autoridad civil, costumbres sociales, opiniones patrísticas e ideas personales. El resultado es que el batiburrillo aumenta. Las colecciones universalistas, que se basan en decretales y concilios ecuménicos, tienden a defender el precepto de la indisolubilidad. Las de signo particularista, partiendo de concilios regionales y libros penitenciales (que compilan penitencias por los pecados e indirectamente normas a cumplir), se acomodan a los usos y problemas de su lugar, aceptando diversos motivos de divorcio. Se miran como causas adulterio los votos religiosos, impotencia, condición servil, no consumación...

Las cosas se van a ir aclarando entre la Reforma Carolingia, siglo IX, que alió poder político y religioso para estructurar la sociedad, y la Reforma Gregoriana, siglo XI, que consiguió para la Iglesia el predominio en la jurisdicción social. Así, tras el primer milenio la Iglesia va a obtener la potestad exclusiva sobre cuestiones matrimoniales, mientras hasta entonces la había compartido con la autoridad secular, o no la había tenido en cuanto sometida a ella. Podrá por fin imponer la disciplina de la indisolubilidad absoluta. Las anteriores colecciones canónicas serán recogidas y reorganizadas en nuevos y más amplios escritos jurídicos, llamados decretos, que irán progresivamente eliminando los pasajes divorcistass6. Y la teología Escolástica contribuirá también a ello desde su sacramentología, la selección de siete ritos especiales de la Iglesia que conferían gracia, en la que incluyó el matrimonio.

55. En el siglo V, dos papas están de acuerdo en el principio de indisolubilidad, pero mientras LEON I (ver nota 54) admite hacer la vista gorda en casos especiales de prisioneros que vuelven a casa y encuentran a su cónyuge nueva y felizmente casado, INOCENCIO I, Carta a Probo 36, no contempla tal. En el siglo VIII GREGorio II, Carta a Bonifacio 2, parece permitir a un marido segundas nupcias por enfermedad que impide el débito a la esposa. Un siglo después, es conocido el choque entre el papa Nicolás I y el rey Lotario II a propósito del divorcio de éste por incesto de la esposa con un hermano del rey (afinidad sobrevenida), a pesar del apoyo al monarca de 3 concilios francos y de Hincmaro de Reims, el obispo más prestigioso de su época.

56. A finales del siglo IX la colección de REgINo DE PRÜM, Las causas sinodales, partiendo de fuentes universalistas y locales, es tanto divorcista como antidivorcista. Más tarde, principios del XI, el Decreto de BURCARDO DE WORMS todavía mantiene dicha esquizofrenia, pero rebajando algo los textos divorcistas. El Decreto de IVo DE CHARTREs, finales del XI, los reducirá mucho más, para quedar expurgados con el Decreto de GRACIANO, a mediados del siglo XII. 
Pero incluso en esta época de liderazgo eclesial, y por tanto de bonanza para sus normas, que se alargará hasta la Reforma Protestante, no desaparecen las excepciones a la indisolubilidad. Todo lo contrario, éstas se fijan para siempre, dado el florecimiento de la ciencia canónica, que hace de este tiempo la edad clásica del derecho. Los teólogos y canonistas bajomedievales, buscando organizar la legislación matrimonial, encuentran una contradicción: por un lado la doctrina del Nuevo Testamento y de los Padres contra todo divorcio, y por otro la práctica eclesial que admitía diversas causas de disolución. Queriendo explicar esta paradoja, y dentro de ella las costumbres divorcistas anteriores, van a centrarse en dilucidar desde cuándo el matrimonio es sacramento, es decir, indisoluble. Descubren así particulares motivos de ruptura del vínculo. Uno es el matrimonio no consumado, porque no realiza plenamente la sacramentalidad, no significa la unión profunda entre Cristo y la Iglesia57. Otro, el privilegio paulino, el matrimonio entre cristiano y no cristiano, que por tanto tampoco era enteramente sacramental, cuando hubiera que defender la fe 58 . Las nuevas situaciones creadas por la evangelización de las culturas halladas en el siglo XVI llevaron a estirar dicho privilegio de la fe en lo que se llamará privilegio petrino, esto es, potestad del papa para disolver un matrimonio no sacramental favoreciendo la fe

57. Motivo aceptado después de una larga disputa de tradiciones y escuelas. La tradición jurídica romana, más sofisticada, decía que el matrimonio existe desde el consenso de los contrayentes. Otra, más prosaica, naturalista y universal, lo establecía en la consumación. En el siglo XII la universidad de París, encabezada por Pedro LomBARdo, Sentencias IV,27,3-4.14, y seguida por los teólogos, defenderá la indisolubilidad desde el consenso. Por el contrario, la universidad de Bolonia, representada por GRACIANO, Decreto II,27,2,34ss, y el apoyo de los canonistas, propiciará la teoría de la consumación. Roma (Decretales de papas juristas, Alejandro III, Inocencio III y Gregorio IX) tirará por la calle de en medio: existe sacramento desde el consentimiento, pero es disoluble si no ha habido cópula. Así lo refiere el actual Código, CIC 1142.

58. Ambrosiaster, Comentario sobre la I carta a los Corintios 7,15, en el siglo IV, llamado así por Erasmo, es el primero que entiende que Pablo permite otro matrimonio cuando la ruptura parte del pagano. Aunque esta interpretación se queda sola entre los Padres, e incluso otros están expresamente en contra (AGUSTIN, Las uniones adulterinas 1,31), se fue desarrollando en los libros penitenciales y colecciones canónicas de los siglos posteriores (Teodoro de Canterbury en el siglo VII, Hincmaro de Reims en el IX, y Burcardo de Worms e Ivo de Chartres en el XI) hasta quedar fijada con Graciano, Decreto II,28,2,2, y PEDRo Lombardo, Sentencias IV,39,5, cuyas obras fueron referencia escolar para canonistas y teólogos. Los supuestos se alargarán algo: no sólo el deseo de ruptura del no creyente, sino también cuando su convivencia es negativa para la fe del cristiano. Así ha quedado hoy día, CIC 1143. 
de un consortes9. En cuanto a los matrimonios ratos (sacramentales) y consumados se desarrollarán las anulaciones, matrimonios no reconocidos como tales aunque se hayan celebrado, al estar prohibidos 60 .

Mientras el Occidente cristiano cerraba filas en torno a la indisolubilidad legal, el Oriente igualmente cristiano tomaba un desvío. En el siglo VI, al tiempo que la parte latina del imperio se reacomodaba a los vientos germánicos, la parte griega se fortificaba cohesionando poder político y religioso. En la legislación matrimonial el emperador Justiniano tradujo esto del siguiento modo: eliminar el divorcio consensual admitiendo el justificado ${ }^{61}$. La sucesión de emperadores bizantinos, añadiendo y quitando supuestos, se balanceará sobre dicho eje. A regañadientes y de modo paulatino la Iglesia fue aceptando esto, necesitada de colaboración con el Estado, ambos amenazados por el Islam. En el siglo X la bendición sacerdotal o ceremonia religiosa es obligatoria para la validez civil del matrimonio62, y la Iglesia reconocerá el divorcio según la legislación temporal. Esta praxis se ha mantenido hasta la actualidad. Comenzarán entonces las justificaciones teológicas del divorcio, interpretando analógicamente las causas que en la Escritura y los Padres señalan el fin del matrimonio, la muerte y el adulterio. Se hablará entonces de muerte moral del consorte, en la que cabe casi todo, desde votos religiosos a malos tratos. La única condición es que venga dictaminado por un juez civil o ecle-

59. La Constitución Altitudo, 1.VI.1537, de Pablo III pedía al polígamo convertido elegir una de sus mujeres, disolviendo las otras uniones; así se refleja en el CIC 1148. La Constitución Populis, 25.I.1585, de Gregorio XIII concedía a un esclavo converso, que ha sido separado del cónyuge por su condición y del que no tiene noticias, volver a casarse; así CIC 1149. Nuestro siglo ha alargado los casos: disolución de matrimonio dispar con dispensa; disolución de matrimonio natural en favor de la fe de un tercero (A está casado con $\mathrm{B}$ y después de divorciarse B se casa con C; convertido C, debiera separarse de B, para la Iglesia casado con A, pues no reconoce el divorcio; en favor de la fe de $C$, para que no tenga que separarse de $B$, la Iglesia disuelve el matrimonio natural de A y B). Ver CONGREGACION DE LA FE, Ut notum est, 6.XII.1973.

60. La nulidad matrimonial ya existía en el derecho romano (por edad, clase social), pero no siempre era aplicada. El concepto firme no se elaborará hasta la canonística del segundo milenio, con su refinamiento y abstracción jurídicas: falta de edad, impotencia, órdenes sagradas, disparidad de religión, parentesco, etc, serán razones disolventes del matrimonio (GAUDEMET 227-256). Prácticamente son los mismos impedimentos dirimentes de hoy, CIC 1083-1094.

61. Novela 117, año 542. Permite el divorcio por entrada en religión de ambos esposos; impotencia; conspiración política; adulterio de la mujer; falsa acusación del marido por adulterio de la esposa; conyugicido tentado; deshonestidad pública (concubinato del marido, asistencia de la mujer a espectáculos y baños sin permiso del esposo); cautividad.

62. Decisión del emperador LEON VI, Novela 89. 
siástico, esto es, sin contemplarse el mutuo acuerdo. Esto derivará en la búsqueda del culpable para la ruptura de un matrimonio, permitiendo otro al inocente. La teología Ortodoxa ha explicado la contradicción entre la doctrina evangélica y la práctica eclesial como una concesión o benevolencia, que llama oikonomía, la no aplicación estricta de una norma, dada la debilidad humana. Así lo perciben en los casos de Mateo y en algunos Padres. Para ellos el matrimonio es comunidad de vida, y el pecado a veces la destruye de hecho. No cabe, dicen, sino dar salida a esta situación ${ }^{63}$.

El movimiento de la Reforma Protestante, rechazando la autoridad papal sobre los fieles, incluyó la normativa eclesial sobre el matrimonio entre las cosas de las que había que liberarse. El matrimonio no era un sacramento, sino una cuestión terrena que concernía al poder temporal. Sobre el divorcio en particular, contando con las divergencias entre los reformadores, dicen que aunque el evangelio es contrario en general, también lo justifica en algunos casos, como por adulterio en Mateo o por comportamiento no cristiano en 1 Cor 7,15 , interpretándolo metafóricamente (abandono, herejía, incumplimiento del débito). Además hay que aceptar la legislación civil. Las Iglesias protestantes admiten así varias causas de divorcio, defendiendo una indisolubilidad relativa del matrimonio. En la práctica han conjugado esto rechazando normalmente la ceremonia eclesial para los divorciados que se vuelven a casar. La Comunión Anglicana, aunque más estricta en la defensa de la indisolubilidad, participa de esta línea de actuación ${ }^{64}$.

Este somero repaso histórico de la práctica cristiana sobre el compromiso nupcial, hasta su fijación y diversificación confesionales en la primera mitad del segundo milenio, muestra que la Iglesia siempre ha tenido que contar con la quiebra conyugal, y que ha debido reglamentarla en su seno, sin excluir a los implicados, aunque sea reconociendo sólo la mera separación. Ha sucedido esto desde el nacimiento de la Iglesia, en los tiempos apostólicos. La palabra de Jesús sobre la indisolubilidad, de hecho, ha sido tomada como una pretensión religiosa que debe hacer las paces con situaciones opuestas.

63. Ver M. Jugle, Mariage dans l'Église gréco-russe: Dictionnaire de Théologie Catholique IX/2, 1927, 2317-2331.

64. Sobre esto L. BRESSAN, La indisolubilidad del matrimonio en el concilio de Trento: Garcia BARBERENA 220-222; A. BellinI, Il matrimonio nel Protestantesimo: T. Goffi (ed.), Enciclopedia del matrimonio, 1965, 316-321. 


\section{V. "MODERNIDAD" DEL DIVORCIO}

La emancipación estatal respecto de la Iglesia, iniciada en la práctica en los países que acogieron la Reforma Protestante, produjo la reaparición de la legislación divorcista. En los países católicos, después de largas escaramuzas políticas (Regalismo) y culturales (Ilustración), que acabaron con el estilo de Cristiandad, dicha legislación estalló con la Revolución Francesa, difundiéndose luego por doquier, síntoma de un rampante secularismo. Los regímenes comunistas de principios de nuestro siglo colaborarán también en ello.

\section{El divorcio en expansión}

El siglo XX ha significado la explosión del divorcio. Si no sonara a chiste podría decirse que es uno de los signos de los tiempos, una de las características que marcan la época. Compartiría estrellato con el avance técnico, que nos hace ver zonas no tocadas por el hombre como parques naturales, maravillas en vías de extinción; o la difusión de la democracia, glorificada últimamente en su versión liberal como cima de la evolución humana65.

Las estadísticas son espeluznantes. En la primera mitad de siglo, al asentarse en Occidente la legislación divorcista, tras los titubeos del siglo anterior, oscila en torno al $10 \%$. En la segunda mitad, a partir sobre todo de los años 70 , en que se retocan las diversas disposiciones legales añadiéndose el divorcio consensuado (sin exponer razones) al divorcio por falta (adulterio, abandono, maltrato...), el porcentaje va a ir subiendo hasta llegar a 1 divorcio de cada 3 matrimonios, e incluso 1 de cada 2, es decir, el $50 \%$. Y eso sin contar que las bodas han disminuido66.

¿Ha alentado la jurisprudencia al divorcio o más bien la sociedad reclamaba tales leyes? La respuesta está en lo segundo, a juzgar por la evolución de las demandas y sentencias de divorcio, que partían cada vez más del fracaso de la vida común, así como por los referéndum y propuestas políticas votados en este sentido. Curiosamente, Occidente ha

65. L. GonZalez-CARVAJal, Los signos de los tiempos. El Reino de Dios está entre nosotros, 1987; F. FUKUYAMA, El fin de la historia y el último hombre, 1992.

66. GAUDEMET 21-23.481-509. 
vuelto a la comprensión matrimonial del derecho romano, basada únicamente en el compromiso de vida compartida.

¿A qué se ha debido este cambio tan profundo, realizado en apenas medio siglo? En primer lugar a la tremenda secularización de la sociedad, que iniciada tiempo atrás política y culturalmente ha sido exaltada y divulgada con el tecnicismo científico del siglo XX; uno de sus rasgos es el fin del poder temporal de la Iglesia, otro la desacralización del matrimonio, que tenían precisamente la indisolubilidad como característica. En segundo lugar, el hecho de la emancipación de la mujer, verdadera revolución de nuestra era, otro de los signos de los tiempos. Su nuevo papel social y familiar, que le da independencia respecto y dentro del matrimonio, ha hecho a éste más frágil, ya que uno de sus puntales era la sujeción femenina. Por último, y este es seguramente el aspecto más decisivo, la creciente percepción del individuo y su autorrealización como fines últimos de la vida. Se manifiesta esto en el aprecio por los valores democráticos (libertad, tolerancia), centrados en la persona; la popularización de la psicología, que busca la curación y comprensión del interior humano; y la preponderancia de corrientes filosóficas individualistas, existencialismo y posmodernidad en cada mitad de siglo. La infelicidad o insatisfacción o mal aguante de la frustración están detrás de todos los fracasos conyugales. Estos sentimientos, además, se han visto exacervados por nuestra cultura capitalista, que prima ganar y recibir, el bienestar, mientras el matrimonio y el amor exigen básicamente lo contrario: dar siempre, muchas veces ceder.

Otros motivos conexos y secundarios serían la mayor duración de la vida común, cuadruplicada con el aumento de la esperanza de vida, que ve aumentadas las ocasiones de crisis. La disociación entre trabajo y familia, que a veces origina conflictos de incompatibilidad. Y el rechazo de los cónyuges a todo apoyo institucional externo (Iglesia, Estado, familia plurigeneracional), que así quedan aislados en su decisión afectiva, sometida a la erosión del tiempo y los roces. Todo eso junto ha provocado el hundimiento de la perdurabilidad del vínculo.

\section{2. ¿Excomulgados o privados de comunión?}

Con la nueva mentalidad y forma de vida plenamente desplegadas, la avalancha de rupturas conyugales no podía dejar de afectar a los fieles cristianos. En 1965 el concilio Vaticano II lo reconoce indirectamente al 
hablar de la "epidemia del divorcio"67. Hoy seguramente tendría que llamarlo endemia, vista la evolución habida.

La acción de la Iglesia se mueve entre dos coordenadas. De un lado el mensaje evangélico, inmutable, definitiva palabra divina manifestada en Jesucristo. De otro, la mentalidad del tiempo, cambiante con la historia, testigo de la evolución humana. No puede dejar de hacerlo así. El evangelio la condiciona en cuanto origen inamovible, de influjo perenne si quiere ser auténtica. La época la permea en cuanto en ella vive y desde ella interpreta todo. La Iglesia se ve así obligada a actuar dentro de una cierta dialéctica. No es sólo que entiende el evangelio desde su época, sino que tiene que proclamarlo a su época, acomodándose a ella para hacerlo comprensible, aunque sin variarlo68.

A pesar de ser el último bastión antidivorcista, también sobre este tema la Iglesia católica ha tenido que moverse. Como para ella el matrimonio sacramental y consumado es absolutamente indisoluble, la flexibilidad hacia los tiempos ha venido a través de las anulaciones matrimoniales, crecidas considerablemente ${ }^{69}$. Se ha llamado a estas nulidades divorcio a la católica, y desde luego tiene todas las trazas. En la legislación civil, al reconocerse el divorcio, apenas se utiliza la vía de la anulación, aunque exista. En la Iglesia católica es el único modo de deshacer un matrimonio sacramental sin contrariar la indisolubilidad legal, de ahí su sofisticación. Pero esto crea una fantasmagoría. Lustros de convivencia, hijos nacidos, prueban que ha habido matrimonio, por más que el derecho canónico lo juzgue inválido o inexistente. ¿Qué decir, si no, de los años e hijos tenidos en común? En realidad se trata de una vía de escape para conyugamien-

67. Gaudium et spes 47b.

68. Es el problema de la evolución de los dogmas, de cómo retraducir conceptos ahora ininteligibles, como el de personas y naturalezas trinitario-cristológicas, o el de sustancia eucarística.

69. A los antiguos impedimentos dirimentes se sumó el defecto de forma canónica, o falta de testigos en el matrimonio, desde que en el siglo XVI la hizo obligatoria el decreto Tametsi del concilio de Trento, para evitar los matrimonios clandestinos, H. DENZINGER, El Magisterio de la Iglesia. Manual de los símbolos, definiciones y declaraciones de la Iglesia, 1963, 991s; CIC 1108,1 . Pero lo que más se ha desarrollado últimamente para la nulidad es el defecto de consentimiento, sobre todo la incapacidad para captar los deberes y derechos esenciales del matrimonio (indisolubilidad, fidelidad, procreación, débito, convivencia), sea transitoria (inmadurez) o permanente (trastornos psíquicos), CIC 1095s. 
tos fallidos. Lo prueba también el hecho de que los matrimonios nulos pero exitosos son convalidados fácilmente ${ }^{70}$.

Pero la mayoría de las quiebras conyugales entre católicos no se resuelven mediante la anulación. De manera que no se resuelven de ninguna manera. Sólo les cabe la separación, sin poder casarse de nuevo. De este modo han aparecido los católicos divorciados reesposados civilmente. Su Iglesia les cuenta entre las uniones irregulares -como la cohabitación o el matrimonio civil-, y les aparta de los sacramentos. Inicialmente, con el Código de Derecho Canónico de 1917, que los consideraba "bígamos" e "infames", fueron excomulgados, lo que suponía exclusión de los sacramentos, de apadrinamientos y de sepultura eclesiástica71. Eran todavía casos relativamente poco numerosos. Tras el Vaticano II, con su reconocimiento de la libertad religiosa y de la autonomía de lo temporal72, se irá suavizando la cuestión. Por ejemplo, se les va a permitir tener funeral cristiano ${ }^{73}$.

La Familiaris consortio (1981), exhortación del papa tras el Sínodo episcopal sobre la familia, tiene el número 84 dedicado a ellos. "Tratándose de una plaga que, como otras, invade cada vez más ampliamente incluso los ambientes católicos, el problema debe afrontarse con atención improrrogable". En él se pide a los pastores solicitud por los divorciados, que se les anime a participar en la oración cristiana y a educar en la fe a sus hijos, pues no deben considerarse "separados de la Iglesia". Pero, de todos modos, "la Iglesia, fundándose en la Sagrada Escritura, reafirma su praxis de no admitir a la comunión eucarística a los divorciados que se casan otra vez".

No puede evitarse en todo esto cierta ambigüedad eclesial, una especie de paso adelante y otro atrás. De un lado, se les dice que no están excomulgados, pero de otro, no se les permite comulgar, el signo más expresivo de integración en la Iglesia, por lo que tienen el mismo nombre de comunión. Por una parte, se pide a los pastores "discernir bien las situaciones", distinguir entre inocentes y culpables en la destrucción de un matrimonio, diferenciar a los que se casan de nuevo responsablemente (para la mejor educación de los hijos, por creer en conciencia inválido el

70. CIC 1156-1165. Por la convalidación simple: renovación del consentimiento sin la forma canónica; o la sanación en la raíz: reconocimiento oficial retroactivo de validez.

71. Cánones 2356 y 2260.

72. Dignitatis humanae 3c; Gaudium et spes 36b.

73. CONGREGACION DE LA FE, Decretum de sepultura ecclesiastica, 20.IX.1973. 
anterior matrimonio), y por otra, se rechaza el mínimo atisbo de salida en esa dirección que no implique continencia sexual en el segundo enlace ${ }^{74}$. Finalmente, mientras se insiste en la necesidad de los sacramentos para la plenitud de vida cristiana, a ellos se les dice que la participación sacramental no lo es todo; precisamente a ellos, que son los que más precisan signos externos de aceptación divina y eclesial.

\section{El pecado contra el matrimonio}

La Iglesia parece comportarse de modo duro e inmisericorde hacia estos divorciados reesposados. Son personas que se agarran casi desesperadamente a la fe, que han pasado por una situación dolorosa matrimonial, que se han sentido fracasadas personalmente y han sido excluidas de la esencia de la Iglesia, todavía humilladas cuando son asimiladas poco menos que a pecadores públicos. No se percibe en ella el anuncio que la constituye, resumido en la desbordante misericordia de Dios predicada por Jesús. Sin embargo, justamente dice actuar así por fidelidad al mensaje de Jesús. La contradicción se antoja clara: guiada por la palabra de Jesús acaba oponiéndose a su buena noticia. La clave de esta aporía es que se considera la disolución del vínculo conyugal -no la separación sino un nuevo matrimonio- como un pecado imperdonable. Por eso no puede practicar completamente el amor de Dios hacia los infractores.

Las razones que da para su postura son que "su estado y situación de vida contradicen objetivamente la unión de amor entre Cristo y la Iglesia. (...) Si se admitieran estas personas a la Eucaristía, los fieles serían inducidos a error y confusión acerca de la doctrina de la Iglesia sobre la indisolubilidad del matrimonio"75. Sobre la razón doctrinal, que los divorciados vueltos a casar contravienen el mandato de Jesús, hay que decir que se parte de un doble error de interpretación por parte de la Iglesia, decantado en la Patrística. La razón pastoral, el error y confusión de los fieles, queda eliminada por el error previo.

74. En 1993, obispos de una provincia eclesiástica alemana, entre los que están dos famosos ex teólogos, Walter Kasper y Karl Lehmann, han intentado una solución agarrándose al párrafo 84b de la Familiaris consortio. Propusieron una admisión particularizada de divorciados recasados a los sacramentos, en casos de convicción de conciencia con acompañamiento de un sacerdote. La respuesta de la Congregación de la Fe rechazó de plano tal posibilidad. Ver Ecclesia, 8.X.1994, 26-38; y 22.X.1994,37s.

75. Familiaris consortio $84 \mathrm{~d}$. 
Si Jesús criticó en su tiempo la Ley judaica, lo que fue una de las característica de su obrar, porque según él tiende a delimitar en lugar de facilitar.la entrega total del hombre a Dios, no se puede pensar que esté imponiendo otra ley, la indisolubilidad matrimonial, entendida socio-jurídicamente (quien la incumpla queda apartado del grupo). Más bien, y en eso consistió su tarea, propone un camino hacia Dios y la plenitud humana, que la teología llama revelación. Amar a los enemigos, no devolver mal por mal, perdonar constantemente, forman parte de este camino. Los desvíos inevitables, el pecado, debieran llevar a retomar la dirección correcta, la conversión, a reiterar esfuerzos en pos de la meta. Como todas las exigencias de Jesús, la indisolubilidad es una invitación religiosa para la felicidad y la salvación. Quien no pueda realizarlas, bastante castigo tiene en ello, y habrá que animarle a renovar su fe y a intentarlo de nuevo.

La primera tradición cristiana, Pablo y Mateo, así lo ha atisbado, ya que junto al ideal moral, expuesto en toda su radicalidad, admite salidas para los caídos, sea separación simple o nuevo matrimonio, por falta de paz o adulterio. La separación será desde entonces una solución fija. Pero pronto, desde el principio de la época Patrística, la exigencia interior se transformó en ley externa. El crecimiento de la Iglesia y la teología sacramental del matrimonio llevaron a ello. Con lo primero, al tener que ordenar su realidad comunitaria, la Iglesia excluyó a los adúlteros, a los que rompían el matrimonio, reintegrándoles sólo tras una dura penitencia pública. Con lo segundo, al indicar el matrimonio cristiano la unión de Cristo y la Iglesia, aquél no se podría romper como tampoco se rompía ésta. Pero como de hecho el compromiso marital se destruía, la significación sólo podía mantenerse prohibiendo otro matrimonio, convirtiéndose en ley un principio moral ${ }^{76}$. Hay que recordar que Pablo no permitía un nuevo matrimonio, en caso de ruptura, para posibilitar de nuevo la avenencia conyugal, casi forzando a ella. Cuando después nadie piense en esta razón de reconciliación, ¿por qué se ha mantenido el efecto? Indudablemente porque se le entiende como ley.

La suerte pareció echada. La Patrística había zanjado la cuestión en favor de la indisolubilidad legal, admitiendo sólo la separación de mesa y lecho en caso de grave discordancia. Pero la conflictividad conyugal fue

76. La Patrística también dudó en permitir segundas nupcias tras la muerte del cónyuge, Crouzel (1971) 374-376, en virtud de la mitificación religiosa del primer compromiso. Por fortuna, la palabra de Pablo ( $\mathrm{Rm} 7,2 \mathrm{~s}$; 1 Cor 7,8s.39) hubo de prevalecer. 
más terca, y la Iglesia tuvo que pactar con ella regulando las rupturas, aunque manteniendo incólume el precepto. $\mathrm{Y}$ si bien la corriente Católica tendió a restringir la disolución completa, las derivaciones Ortodoxa y Protestante tomaron la dirección contraria. Una, dice, llevada de conmiseración ante los dramas familiares. La otra, tras constatar que la legislación del matrimonio no es asunto suyo, que más bien se centra en la asistencia pastoral.

Pero en la Iglesia Católica, una equivocada idea de la pretensión de Jesús, juridizando su exigencia moral, así como el predominio de la significación trascendente del matrimonio sobre el compromiso humano, o embeleso sacramental, han lastrado la-percepción de la indisolubilidad hasta hoy. Sin embargo, la Iglesia Católica debiera aprender en esto de ortodoxos y protestantes, igualmente seguidores de la fe cristiana y tan dignos de crédito en su buena voluntad como ella. Presuponiendo sus errores, como en otras cosas y como todos, parecen haber acertado algo más. La Iglesia Ortodoxa acepta las disoluciones dictadas por la autoridad civil, autorizando a la parte inocente un nuevo matrimonio religioso. Ultimamente también a la culpable, si da muestras de contrición y después de una penitencia. La objeción sería que no siempre está clara la adscripción de culpa en un fracaso conyugal, más bien suele ser algo compartido. Los protestantes, dentro de su variedad, dejando la legislación matrimonial al Estado, celebran una ceremonia religiosa sin efecto civil, que no repiten en general en caso de divorcio, señalando así la obligación cristiana de la indisolubilidad; a éstos, de todos modos, no les excluyen de la eucaristía. Sería, pues, un asunto más de la urgente tarea ecuménica, alentada por el Vaticano II pero todavía pendiente ${ }^{77}$.

Además, el uso actual católico de la indisolubilidad supone considerar la ruptura matrimonial como un pecado imperdonable. Esto contradice el mensaje evangélico, así como se opone a la tradición bimilenaria de la Iglesia. Ningún pecado, por grave que sea, es irremisible. Ahora bien, los católicos que malogran su matrimonio, por las culpas de uno u otro, excepto los pocos que consiguen disolverlo o anularlo, quedan condenados de por vida con el estigma de su pecado. Si quieren seguir dentro de la Iglesia no pueden volver a casarse y reiniciar una vida familiar plena,

77. "Promover la restauración de la unidad entre todos los cristianos es uno de los principales propósitos del concilio ecuménico Vaticano II" (Unitatis redintegratio 1a). Esta declaración, que abre el decreto sobre el ecumenismo, no parece haberse tomado muy a la letra. 
por necesidad propia o por la atención a los hijos. Y si se casan quedan proscritos de la entera comunión con la Iglesia ${ }^{78}$, apartados de los símbolos de la fe más cotidianos y gratificantes, el perdón de Dios y la intimidad con Él, y a través de esto obtener lo mismo de la comunidad. Todavía creyentes y con su sufrimiento familiar a cuestas, son los que más desean y necesitan recibir esos sacramentos. Como suele ocurrir, sólo se aprecia verdaderamente lo que no se tiene. Así las cosas, parece preferible matar al cónyuge, y luego arrepentirse y ser readmitido en la Iglesia, que divorciarse de él, broma que ya apareció en la antigüedad cristiana79.

Católico, divorciado y reesposado son componentes de un círculo doloroso y sin salida. Tal vez han pecado -en el mejor de los casos, tal vez no- contra el matrimonio, llevándolo a la ruina. Si no se casan otra vez el pecado ya existe, aunque por lo visto no se tiene en cuenta. Pero este pecado no puede ser peor que otros, peor incluso que el mayor pecado, por ejemplo el pecado original de la teología tradicional, hasta el punto de no poder perdonarse y permitir otra oportunidad. Como todos, será remisible mediante el arrepentimiento y la enmienda y la reparación. El perdón cristiano, imitando el divino, conlleva un nuevo comienzo, borrando todo el mal pasado. Posibilita una nueva vida, plenamente humana, integrada en la comunidad de salvación que es la Iglesia. No puede haber pecado que sobrepuje tal perdón.

Tomás Marcos Martínez, osa

Estudio Teológico Agustiniano

Valladolid

78. A no ser que vivan con su cónyuge como si fuera su hermano, Familiaris consortio 84e. De esto uno no sabe si pensar que es ridículo o simplemente contradictorio.

79. Es una de las objeciones de Polencio a la práctica de la Iglesia, que intenta refutar Agustin, Las uniones adulterinas 2,14-16, sin lograrlo del todo. Por mucho que diga, el adulterio se penaliza más que el homicidio, inversamente a su gravedad. 